\title{
MOLECULAR IDENTIFICATION OF Pepper yellow leaf curl Indonesia virus ON CHILI PEPPER IN NUSA PENIDA ISLAND
}

\author{
Dewa Gede Wiryangga Selangga ${ }^{1} \&$ Listihani $^{2}$ \\ ${ }^{1}$ Faculty of Agriculture, Warmadewa University, Indonesia \\ Jl. Terompong No. 24 Tanjung Bungkak Denpasar Bali 80239 \\ ${ }^{2}$ Faculty of Agriculture and Business, University of Mahasaraswati Denpasar, Indonesia \\ Jl. Kamboja No. 11A Dangin Puri Kangin Denpasar Utara Bali 80233 \\ E-mail: listihani9@gmail.com
}

Manuscript received: 9 March 2021. Revision accepted: 27 April 2021.

\begin{abstract}
Molecular identification of Pepper yellow leaf curl Indonesia virus on chili pepper in Nusa Penida Island. Pepper yellow leaf curl Indonesia virus (PYLCIV) has been reported as caused yellow leaf curl disease in Bali Island since early 2012. Dominant symptoms of Pepper yellow leaf curl virus (PYLCV) infection in chili pepper were yellowing, leaf curl, yellow mosaic, and mottle. Bemisia tabaci, has been known to vector on the case yellow leaf curl disease. Observations on the Nusa Penida Island in 2020 showed symptoms such as yellow leaf curl disease, however, identification of PYLCV in Nusa Penida Island has not been studied. Molecular identification was conducted using polymerase chain reaction and sequence analysis. Data collected in this study was disease symptoms and disease incidence. The results showed that dominant disease symptoms caused by virus from Nusa Penida were yellow mosaic, yellowing, and mottle. Universal DNA fragments of 912 bp were successfully amplified from 50 leaf samples using Begomovirus degenerate primers SPG 1 (5'-CCCCKGTGCGWRAATCCAT3') and SPG 2 (5'ATCCVAA YWTYCAGGGAGCT-3'). Sequence analysis showed that the isolate from Nusa Penida was a Pepper yellow leaf curl Indonesia virus (PYLCIV) which was closely related to PYLCIV from Bali (95-100\% of homology), PYLCIV from Java (94\% of homology), PYLCV from India (70\% of homology) and PYLCV from Thailand (65\% of homology).
\end{abstract}

Key words: Begomovirus, homology, molecular identification, polymerase chain reaction

\section{INTRODUCTION}

Yellow leaf curl disease is one of the major constraint of chili pepper production in Indonesia. This disease is caused by Pepper yellow leaf curl virus (PYLCV) that was firstly reported in Central Java and resulting in yield loss of 20-100\% (Setiawati et al., 2008). PYLCV distributes fastly on chili crop in Indonesia. The incidences of yellow leaf curl disease have been reported from various regions in Indonesia, including from Central Java, West Java, Yogyakarta and Lampung since the early 2000 (Sulandari et al., 2006).

The symptom of yellow leaf curl disease associated with Pepper yellow leaf curl virus (PYLCV) on chili pepper was first found in Bali in 2012 (Nyana, 2012). The incidence of the disease on chili in Payangan district, Bali was up to $22.75 \%$ (Putra et al., 2015). The disease was rapidly spreading in Bali because chili pepper was cultivated continuously in some areas, such as in Karangasem, Bangli, Tabanan, Gianyar, Buleleng, Badung, Klungkung and Jembrana. It caused the production of chili pepper in these areas declined significantly, from 48,788 tons in 2014 to 45,386 tons in 2015 (BPS Bali, 2015).

PYLCV belongs to the genus of Begomovirus with its single-stranded DNA encapsulated in icosahedral twin particles (Brown et al., 2012). Begomovirus transmission can only occur through its vector insects i.e. the whitefly, Bemisia tabaci (Hemiptera: Aleyrodidae) (De Barro et al., 2008). B. tabaci transmitted PYLCV in persistently manner with acquisition and inoculation period up to for 24 hours (Gaswanto et al., 2016). Members of the genus Begomovirus are known to have a high genetic diversity. Based on the polymerase chain reaction-restriction fragment length polymorphism (PCR-RFLP) technique, Tomato leaf curl virus (ToLCV) on tomatoes in Java and Sumatra showed vary, indicating the presence of genetic diversity among isolates (Santoso et al., 2008). Trisno et al. (2009) reported a kinship relationship between the isolates of Pepper yellow leaf curl Indonesia virus (PYLCIV) from West Sumatra with PYLCV from West Java, although there is a variation of nucleotide in the common region. 
The severity of the disease in the field is determined by several factors, including environmental conditions, plant responses and pathogen virulence. Based on some previous research, it is known that the severity of chronic yellow leaf curl disease is strongly influenced by the response of chili cultivar and the virulence of PYLCIV. The diversity of PYLCIV strains is the cause of different symptoms of infection in chili pepper. Because the PYLCIV strain infecting the chili pepper in Nusa Penida Island has not been identified yet, it is necessary to conduct a research on the characterization of PYLCIV isolate from Nusa Penida Island.

\section{MATERIALS AND METHODS}

Research Site. This research was conducted from August 2020 to February 2021 at the Molecular Biotechnology Laboratory, Warmadewa University. A survey to collect symptomatic samples of chili pepper were collected from chili pepper planting area in Nusa Penida Island.

Field Observation and Disease Incidence Analysis. The observations disease symptoms and incidence were conducted during samples collections. The incidence of disease was calculated based on the proportion of diseased plants in a population using formula:

$$
\mathrm{I}=\left(\frac{\mathrm{n}}{\mathrm{N}}\right) \times 100 \%
$$

$\mathrm{I}=$ disease incidence $(\%)$,

$\mathrm{n}=$ number of the diseased plants,

$\mathrm{N}=$ the total number of the observed plants.

Total DNA Isolation from the Diseased Plants and PCR Amplification. Total DNA extraction from the diseased plants was performed using CTAB (Doyle \& Doyle, 1987). Amplification of target viral DNA was performed using ready to go PCR bead (Amersham Pharmacia Biotech. Inc.). The reaction consisted of $2 \mu \mathrm{L}$ of total DNA, $1 \mu \mathrm{L}$ of each SPG 1 (5'CCCCKGTGCGWRAATCCAT-3') and SPG 2 (5'ATCCVAAYWTYCAGGGAGCT-3') (Li et al., $2004)$ with $1 \mu \mathrm{L}$ of concentration and distilled water until the total reaction volume up to $25 \mu \mathrm{L}$. The amplification was performed using PCR machine (Gene Amp, PCR System 9700 PE Applied Bio-system) for 35 cycles. The DNA was analyzed by electrophoresis on $1 \%$ agarose gel in a buffer solution of $0.5 \times \mathrm{TBE}$ (Tris borate-EDTA) and soaked inethidium bromide solution $(10 \mathrm{mg} / \mathrm{L})$ for $10 \mathrm{~min}$. The DNA was visualized under the UV transilluminator and documented digitally.

Identification of PYLCV Based on Sequence Analysis. The PCR product of the target viral DNA were sent to $1^{\text {st }}$ Apical Science, Malaysia. The obtained sequencing data were compared with those at the Genebank and analyzed using BioEdit V.7.0.5 software program (Geneious) (Tamura et al., 2013), CLC Sequence Viewer 8 (Geneious) (Tamura et al., 2013), and MEGA 6.06. Phylogenetic tree was contructed using Mega 6.06 (Algorithm Neighbor Joining with 1,000 bootstraps replicates) (Tamura et al., 2013).

\section{RESULTS AND DISCUSSION}

Disease Symptoms and Incidence. Incidence of yellow leaf curl disease were observed i.e 90 to $100 \%$ in most growing areas. Infected plants were easily recognized in the field based on visual symptoms. Unique symptoms of PYLCIV infection was observed in the field, involving yellow mosaic, mottle, and yellowing (Figure 1). Symptoms variability was found for each region (Table 1).

Green mosaic on the top of leaf was the early symptom chili pepper infecting viruses, followed by cupping upward or cupping downward and yellowing,

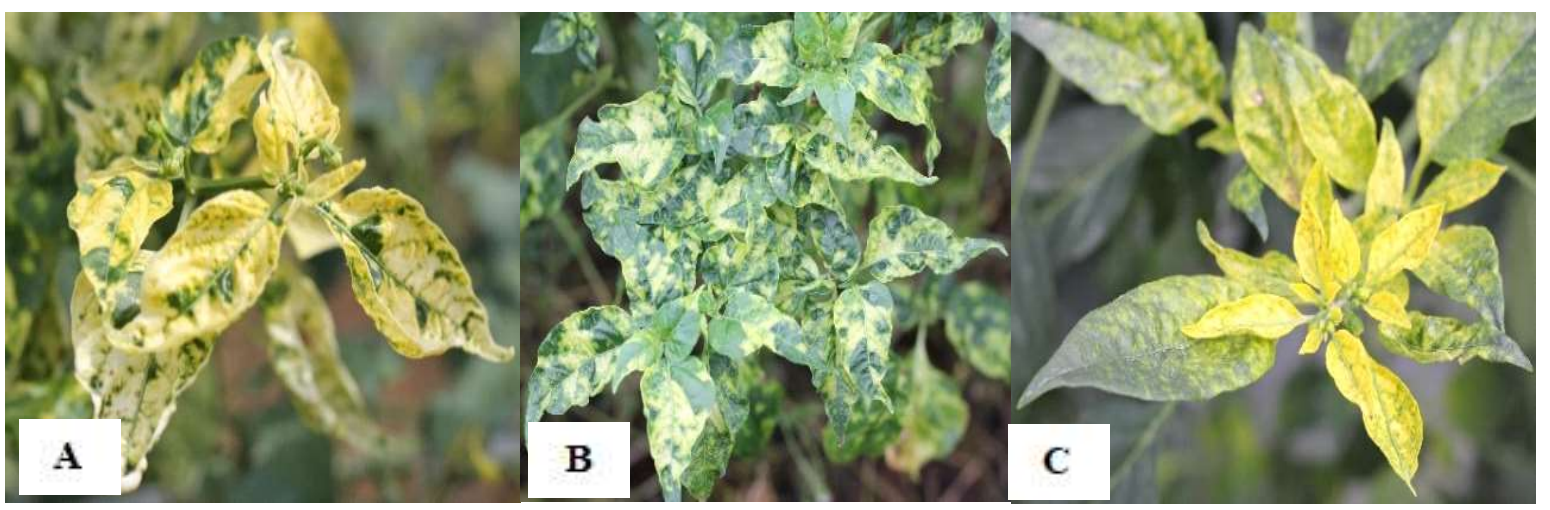

Figure 1. Symptoms of yellow leaf curl disease on chili pepper. (A) Yellow mosaic; (B) Mottle; (C) Yellowing. 
plants will become dwarfs when infected with the virus as the seeds form. These types of symptoms had also been reported as typical of yellow leaf curl disease of chili pepper in Bali Island, Indonesia (Selangga et al., 2019). The type of symptoms associated with the disease in Bali Island is same as those from West Sumatra and Java, which yellowing, mosaic, curling, cupping and stunting were commonly found in West Sumatera (Trisno et al., 2009) and bright yellow colouring was observed in Java (Sulandari, 2004).

Rahim et al. (2015) reported that symptoms of viral infections found in the field showed similarities or variations in symptoms caused by viruses. Plant varieties and environmental conditions influence the expression of symptoms. The same symptoms type of the disease between Nusa Penida, Bali, Java and West Sumatra Island may be caused by the same of i.e. (i) the type of cultivar used, where chili pepper cultivars that are generally planted in Nusa Penida Island is the local cultivar "Seret" and hybrid cultivar Pelita 8. Meanwhile, the cultivar that is generally planted in West Sumatera is the local cultivar "lado keriting darek" (Trisno et al., 2009) and Java are an introduction cultivar, such as TM 999, TM 888 and Jatilaba (Sulandari, 2004), (ii) the strain of begomovirus; this research showed the same strains of begomovirus existed between Bali, West Sumatera and Java. The high incidence, disease severity, and viral incubation time are affected by the number of cuticle buds at the time of transmission.

Leaf morphology is believed to be one of the factors influencing the resistance of a genotype to PYLCV infection. Three varieties of chili found in the field including local varieties "Seret", Pelita 8 and Rawita were reported to have the same morphology with $35 \mathrm{C} 2$ genotype. Ganefianti et al. (2011) reported that the 35C2 genotype had a mild trichome, a thin epidermis layer, and a palisade. It is believed that the relatively thin leaf morphology affects the eating behavior of the whitefly so that the virus can be easily transmitted. Faizah et al. (2012) reported that feeding and egg-laying activities were strongly influenced by morphology and leaf characteristics such as leaf color, leaf shape, trichome and chemical compounds derived from secondary metabolic processes. This statement was also made by Lapidot et al. (2001) in his journal. The knowledge of plant morphological features that play a role in structural resistance to pathogen infections needs to be further investigated. It is closely linked to efforts to assemble disease-resistant.

Distribution of PYLCV in Bali. Universal DNA fragments of $912 \mathrm{bp}$ were successfully amplified from 50 leaf samples using Begomovirus degenerate primers SPG 1 (5'-CCCCKGTGCGWRAATCCAT-3') and SPG 2 (5'ATCCVAAYWTYCAGGGAGCT-3') (Li et al., 2004) (Table 2). Ten isolates from 50 samples representing 10 different locations with specific symptoms were subjected to direct sequencing (Figure 2).

\section{Sequence Characterization and Phylogenetic} Analysis. The relationship between isolates of PYLCIV from Nusa Penida Island and other selected PYLCIV in GeneBank was evaluated based on "top fragment" sequences. Ten PYLCIV isolates determined in this research could be differentiated into three groups (Figure 3 ). The first group consisted of 15 isolates including ten isolates from Nusa Penida Island and 5 isolates from Bali Island. The second group of PYLCIV infecting chili pepper in Indonesia that have been reported earlier [PYLCIV Sumatera-Smt (Acc. No. LC051113), PYLCIV Bogor-Bgr (Acc. No. AB267838), PYLCIV Bogor-Bgr (Acc. No. DQ083764), and PYLCV Idn (Acc. No. JX416180)]. Two isolates from other Asian

Table 1. Characteristic of field symptoms and disease incidence of pepper yellow leaf curl disease in Nusa Penida Island, Indonesia

\begin{tabular}{lllc}
\hline Location (village) & Cultivar & \multicolumn{1}{c}{ Symptoms } & Disease incidence (\%) \\
\hline Ped & Local Seret & Yellowing & 100 \\
Klumpu & Pelita 8 & Yellowing, dwarf & 90 \\
Batukandik & Kresna & Yellow mosaic & 100 \\
Bunga Mekar & Prabu & Mottle & 100 \\
Sakti & Pelita 8 & Yellowing & 100 \\
Batumadeg & Maraton & Yellow mosaic, mottle & 100 \\
Sekar Taji & Gada & Mottle & 90 \\
Kutampi & Pelita 8 & Yellowing & 100 \\
Toya Pakeh & Local Seret & Dwarf, yellowing & 90 \\
Kutampi Kaler & Local Seret & Yellow mosaic & 100 \\
\hline
\end{tabular}


Table 2. Detection of Begomovirus from leaf samples collected in Nusa Penida Island

\begin{tabular}{lllc}
\hline Location (village) & Cultivar & \multicolumn{1}{c}{ Symptoms } & PCR detection \\
\hline Ped & Local Seret & Yellowing & + \\
Klumpu & Pelita 8 & Yellowing, dwarf & + \\
Batukandik & Kresna & Yellow mosaic & + \\
Bunga Mekar & Prabu & Mottle & + \\
Sakti & Pelita 8 & Yellowing & + \\
Batumadeg & Maraton & Yellow mosaic, mottle & + \\
Sekar Taji & Gada & Mottle & + \\
Kutampi & Pelita 8 & Yellowing & + \\
Toya Pakeh & Local Seret & Dwarf, yellowing & + \\
Kutampi Kaler & Local Seret & Yellow mosaic & + \\
\hline
\end{tabular}

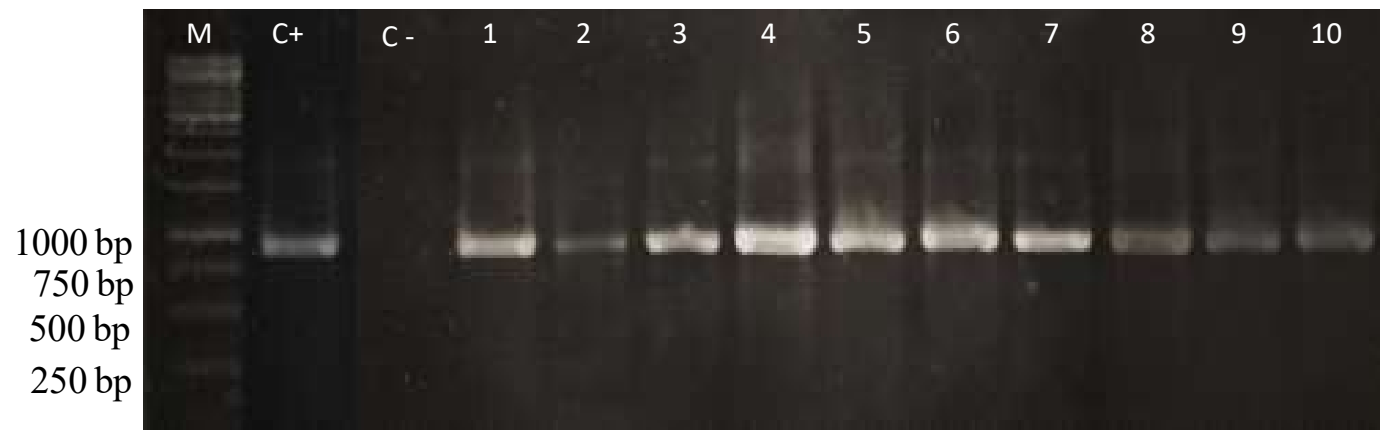

Figure 2. Visualization of DNA amplification of PYLCIV from leaf samples using universal primers SPG1/SPG2 on 1\% gel agarose: $(\mathrm{M})$ DNA marker (1kb ladder); $(\mathrm{C}+$ ) control positif PYLCIV Isolat Bali (LC381280); (1 to 12) field samples from Ped, Klumpu, Batukandik, Bunga Mekar, Sakti, Batumadeg, Sekar Taji, Kutampi, Toya Pakeh, and Kutampi Kaler, respectively.

countries clustered in group 3, [PYLCIV India-IND (Acc. No. JN663870) and PYLCV Thailand-THA (Acc. No. KX943290)]. Tomato leaf curl New Delhi virus from Nganjuk, Indonesia did not belong to the three big group, however, they are outside of out groups.

Analysis of their identity PYLCIV isolates from Nusa Penida Island by comparing to sequence on the GenBank showed their highest homology with Pepper yellow leaf curl Indonesia Virus (PYLCIV) from Bali i.e. $>95 \%$, followed by PYLCIV from Indonesia i.e. $>94 \%$. Their homology to PYLCV, another virus causing yellow leaf curl disease in Thailand and India was only $65 \%$ to $70 \%$.

The results of the genetic diversity analysis also point to the presence of genetic diversity among PYLCV isolates from the analyzed of Bali province. This high genetic diversity is thought to be caused by genetic recombination between the isolates. As described by Kitamura et al. (2004) that recombination of the
Begomovirus is a common and frequent phenomenon in the same Begomovirus species, even in isolates of the same genus.

In this result, 19 isolates were a Pepper yellow leaf curl Indonesia strain Bali, since, according to the guidelines of the International Committee for Taxonomy of Viruses (ICTV), the amino acid sequence of the genetic envelope protein (CP) between a virus and another virus is more than $90 \%$, it is said that the virus is the same species (Padidam et al., 1995).

Pepper yellow leaf curl virus was confirmed as the major virus infecting chilli pepper in Nusa Penida Island. Sequence homology of the virus showed a close relationship with Pepper yellow leaf curl Indonesia virus (PYLCIV) that has been reported earlier infecting chili pepper in Java, but different from those reported in other countries. This fact suggests that PYLCIV is a distinct virus and has the potency to spread across the country. 


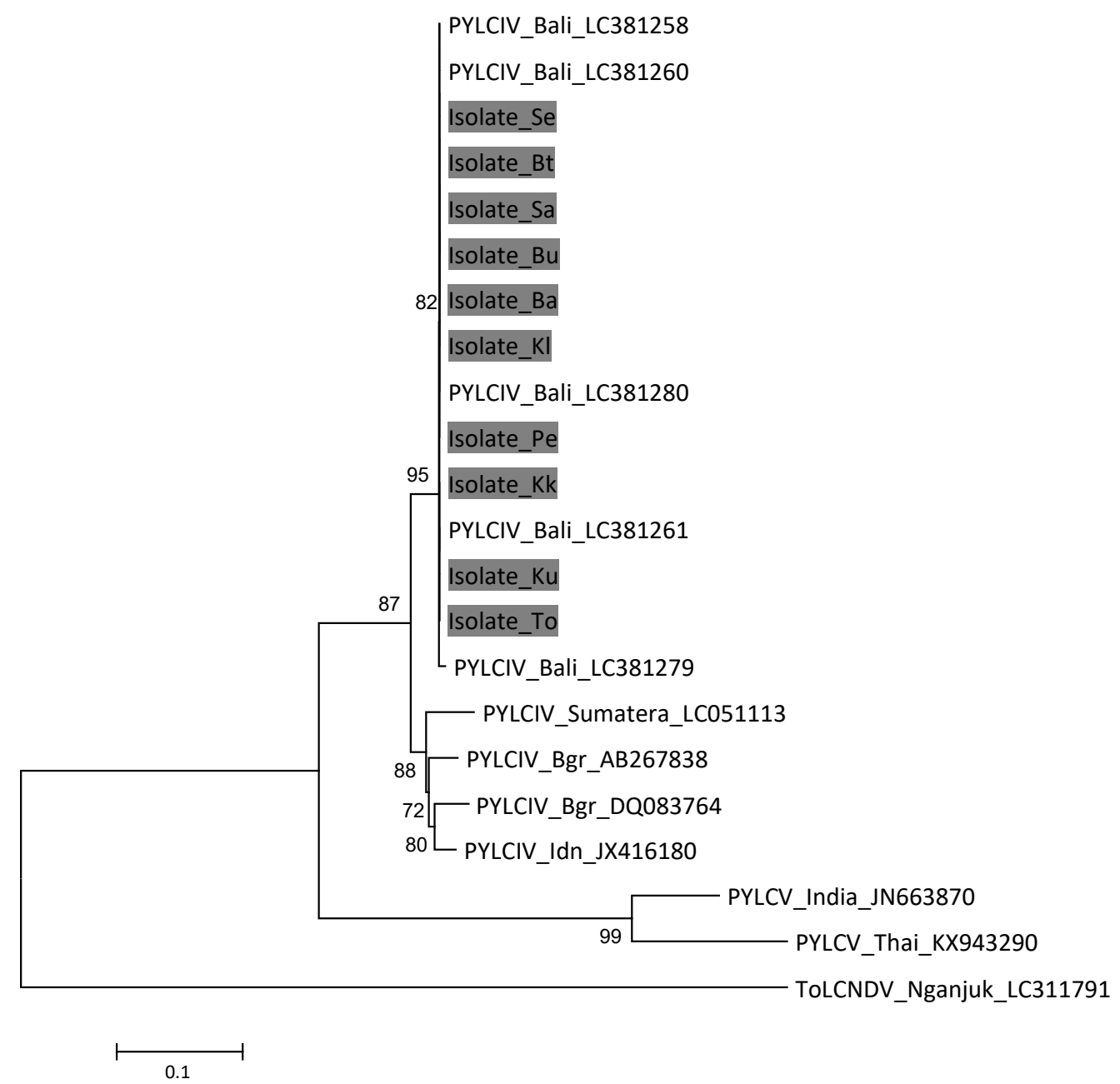

Figure 3. Phylogenetic analysis of Pepper yellow leaf curl Indonesia virus based on alignment of partial nucleotide sequences of the DNA-A of Begomovirus using Mega 6.06. (Algorithm Neighbor Joining with 1,000 bootstraps replicates). Tomato leaf curl New Delhi virus (ToLCNDV) (Acc No. LC311791) from Nganjuk (Ngj) as outgroup.

\section{CONCLUSION}

Based on nucleotide sequences analysisthe yellow leaf curl disease of chili pepper in Nusa Penida Island caused by PYLCIV. The highest similarity of PYLCIV from Nusa Penida Island to corresponding isolates in the GenBank closely with Pepper yellow PYLCIV from Bali (95-100\%), 94\% PYLCIV from Java isolates and to Thailand (65\%) and India (70\%), respectively.

\section{ACKNOWLEDGMENTS}

This research was funded by Budi Tjahjono Awards.

\section{REFERENCES}

BPS Bali. 2015. Chili Production in Bali Province by Regency/City 2011-2015. Badan Pusat Statistik. Bali, Indonesia.

Brown JK, Fauquet CM, Briddon RW, Zerbini FM, Moriones E, \& Navas-Castillo J. 2012. Family Geminiviridae. In: King AMQ, Adams MJ, Carstens EB, \& Lefkowitz EJ (Eds.). Virus Taxonomy. Ninth report of the international committee on taxonomy of viruses. pp 351-373. Elsevier Academic Press, London. 
De Barro PJ, Hidayat SH, Frohlich DR, Subandiyah S, $\&$ Ueda S. 2008. A virus and its vector, pepper yellow leaf curl virus and Bemisia tabaci, two new invaders of Indonesia. Biol. Invasions. 10(4): 411-433.

Doyle JJ \& Doyle JL. 1987. A rapid DNA isolation procedure for small quantities of fresh leaf tissue. Phytochem. Bull. 19(1): 11-15.

Faizah R, Sujiprihati S, Syukur M, \& Hidayat SH. 2012. Ketahanan biokimia tanaman cabai terhadap Begomovirus penyebab penyakit daun keriting kuning. JFI. 8(5): 138-144.

Ganefianti DW, Sujiprihati S, Hidayat SH, \& Syukur M. 2011. Morfologi jaringan daun dan kandungan asam salisilat pada respon ketahanan cabai terhadap infeksi Begomovirus. In: Poerwanto R, Susanto S, Susila AD, Khumaida N, Sukma D, Suketi K, \& Ardhie IW (Eds.). Prosiding Seminar Nasional Perhimpunan Hortikultura Indonesia 2011. pp. 165-174. Balitsa, Lembang, Indonesia.

Gaswanto R, Syukur M, Hidayat SH, \& Gunaeni N. 2016. Identifikasi gejala dan kisaran inang enam isolat Begomovirus cabai di Indonesia. J. Hort. 26(2): 223-234.

Kitamura K, Murayama A, \& Ikegami M. 2004. Evidence for recombination among isolates of Tobacco leaf curl Japan virus and Honeysuckle yellow vein mosaic virus. Arch. Virol. 149(6): 1221-1229.

Lapidot M, Friedmann M, Pilowsky M, Ben-Joseph R, \& Cohen S. 2001. Effect of host plant resistance to Tomato yellow curl virus (TYLCV) on virus acquisition and transmission by its whitefly vector. Phytopathology. 91(12): 1209-1213.

Li R, Salih S, \& Hurtt S. 2004. Detection of Geminiviruses in sweetpotato by polymerase chain reaction. Plant Dis. 88(12): 1347-1351.

Nyana DN. 2012. Isolasi dan Identifikasi Cucumber Mosaic Virus Lemah untuk Mengendalikan Penyakit Mosaik pada Tanaman Cabai (Capsicum spp.). Dissertasion. Udayana University, Bali.

Padidam M, Beachy RN, \& Fauquet CM. 1995. Classification and identification of geminivirus using sequence comparations. J. Gen. Virol. 76(2): 249-263.
Putra IGNBP, Puspawati NM, Nyana IDN, Siadi IK, \& Suastika G. 2015. Identifikasi virus yang berasosiasi dengan penyakit mosaik, kuning, dan klorosis pada tanaman cabai rawit (Capsicum frutescens L.). J. Agroekoteknologi Tropika. 4(3): 244-252.

Rahim YF, Damayanti TA, \& Ghulamahdi M. 2015. Detection of viruses infecting soybean in Java. JFI. 11(2): 59-67.

Santoso TJ, Hidayat SH, Herman M, Aswidinnoor H, \& Sudarsono. 2008. Identitas dan keragaman genetik Begomovirus yang berasosiasi dengan penyakit keriting pada tomat berdasarkan teknik Polymerase Chain Reaction (PCR)-Restriction Fragment Length Polymorphism (RFLP). J. AgroBiogen. 4(1): 9-17.

Selangga DGW, Hidayat SH, Susila AD, \& Wiyono S. 2019. The effect of silica $\left(\mathrm{SiO}_{2}\right)$ to the severity of yellow leaf curl disease on chili pepper. JPTI. 23(1): 54-60.

Setiawati W, Udiarto BK, \& Soetiarso TA. 2008. Pengaruh varietas dan sistem tanam cabai merah terhadap penekanan populasi hama kutu kebul. J. Hort. 18(1): 55-61.

Sulandari S, Suseno R, Hidayat SH, Harjosudarno J, \& Sosromarsono S. 2006. Detection and host range study of virus associated with pepper yellow leaf curl disease. Hayati J. BioSci. 13(4): 1-6.

Sulandari S. 2004. Karakterisasi Biologi, Serologi dan Aanalisis Sidik Jari DNA Virus Penyebab Penyakit Daun Keriting Kuning Cabai. Dissertation. Bogor Agricultural University. Bogor.

Tamura K, Stecher G, Peterson D, Filipski A, \& Kumar S. 2013. MEGA6: Molecular evolutionary genetics analysis version 6.0. Mol. Biol. Evol. 30(12): 2725-2729.

Trisno J, Hidayat SH, Habazar T, Manti I, \& Jamsari. 2009. Detection and sequence diversity of Begomovirus associated with yellow leaf curl disease of pepper (Capsicum annuum) in West Sumatra, Indonesia. Microbiol. Indones. 3(2): 56-61. 